\title{
JABATAN NOTARIS DALAM PERSPEKTIF HUKUM ADMINISTRASI
}

\section{Muhammad Hadin Muhjad}

Fakultas Hukum Universitas Lambung Mangkurat. Jl.Brigjend H.Hasan Basri Banjarmasin 70123 Indonesia Fax:05114321658+E-mail :hadinmuhjad@gmail.com

Submitted : 21/01/2018 Reviewed 25/03/2018 Accepted:29/03/2018

\begin{abstract}
Notary is a public official, authorized to make an authentic deed. Notary is appointed and dismissed by the Government and supervised by the Supervisory Board. Although it is not part of the government but it is publicly responsible in exercising its authority
\end{abstract}

Keywords: Position; Notary; Administrative Law

\begin{abstract}
Abstrak: Notaris adalah merupakan pejabat publik, yang berwenang membuat akta authentik. Notaris diangkat dan diberhentikan oleh Pemerintah dan diawasi oleh Majelis Pengawas. Meskipun bukan merupakan bagian dari pemerintah tetapi dalam melaksanakan kewenangannya bertanggungjawab secara publik.
\end{abstract}

Kata kunci: Jabatan; Notaris; Hukum Administrasi

\section{PENDAHULUAN}

Sepintas jabatan notaris seperti pegawai swasta, karena bekerjanya tidak terikat dengan pemerintah, kantornya menentukan sendiri walaupun ada wilayahnya, karyawannya juga ditentukan sendiri termasuk waktu bekerjanya. Apakah dengan hal ini seorang Notaris lalu merupakan jabatan wiraswasta? Sehingga banyak mempertanyakan apakah jabatan Notaris bukan jabatan pemerintahan atau hanya merupakan jabatan swasta? Siapa sebenarnya yang disebut dengan Notaris? Siapa Notaris itutelah diberikan pengertian dalam dalam Pasal 1 Undang-Undang No. 30 Tahun 2004 tentang Jabatan Notaris bahwa Notaris adalah pejabat umum yang berwenang untuk membuat akta otentik dan kewenangan lainnya sebagaimana maksud dalam undangundang ini.

Dari ketentuan Pasal 1 UndangUndang No. 30 Tahun 2004 tersebut jelas menyebutkan bahwa Notaris adalah sebuah jabatan. Yang dimaksud dengan jabatan adalah kedudukan yang menunjukkan tugas, tanggung jawab, wewenang, dan hak seorang pegawai dalam rangka suatu satuan organisasi ${ }^{1}$, yang telah diatur dalam peraturan perundang-undangan. Selain istilah Pejabat Umum dalam peraturanperundang-undangan ada istilah lain lagi seperti istilah Pejabat Negara, atau Pejabat daerah, selain itu ada

1 Peraturan Pemerintah Nomor 15 Tahun 1994 tentang Pengangkatan Pegawai Negeri Sipil dalam Jabatan Struktural 
juga Badan atau Pejabat Tata Usaha Negara, yaitu Badan atau Pejabat yang melaksanakan urusan pemerintahan berdasarkan peraturan perundang-undangan yang berlaku. Penjelasan pasal tersebut, yang dimaksud dengan urusan pemerintahan ialah kegiatan yang bersifat eksekutif. Istilah Pejabat Umum merupakan terjemah dari istilah Openbare Amtbtenaren yang terdapat dalam Pasal 1 Undang-Undang No. 30 Tahun 2004 dan Pasal 1868 Burgerlijk Wetboek (BW). Pasal 1 Undang-Undang No. 30 Tahun 2004 menyebutkan bahwa:

De notarissen zijn openbare ambtenaren, uitsluitend bevoegd, om authentieke akten op te maken wegens alle handelinggen, overeenkomsten en beschikkingen, waarvan eene algemeene verordening gebied t of de belanghebbenden verlangen, dat bij authentiek geschrift bkijken zal, daarvan de dagteekening te verzekeren, de akten in bewaring te houden en daarvan grossen, afschriften en uittreksels uit te geven; alles voorzoover het opmaken dier akten door eene algemeene verordening niet ook aan andere ambtenaren of personen opgedragen of voorhebehouden is. (Notaris adalah pejabat umum yang satu-satunya berwenang untuk membuat akta otentik mengenai semua perbuatan, perjanjian dan penetapan yang diharuskan oleh suatu peraturan umum atau oleh yang berkepentingan dikehendaki untuk dinyatakan dalam suatu akta otentik, menjamin kepastian tanggalnya, menyimpan aktanya dan memberikan grosse, salinan dan kutipannya, semuanya sepanjang pembuatan akta itu oleh suatu peraturan umum tidak juga ditugaskan atau dikecualikan kepada pejabat atau orang lain).
Pasal 1868 Burgerlijk Wetboek (BW) menyebutkan:

Eene authentieke acte is de zoodanige welke in de wettelijken vorn is verleden, door of ten overstaan van openbare ambtenaren die daartoe bevoegd zijn ter plaatse alwaar zulks is geschied. (Suatu akta otentik ialah suatu akta yang dibuat dalam bentuk yang ditentukan undang-undang oleh atau di hadapan pejabat umum yang berwenang untuk itu di tempat akta itu dibuat). ${ }^{2}$

Menurut kamus hukum arti dari Ambtenaren adalah Pejabat ${ }^{3}$. Dengan demikian Openbare Ambtenaren adalah pejabat yang mempunyai tugas yang bertalian dengan kepentingan publik, sehingga tepat jika Openbare Ambtenaren diartikan sebagai Pejabat Publik. ${ }^{4}$ Khusus berkaitan dengan Openbare Ambtenaren yang diterjemahkan sebagai Pejabat Umum diartikan sebagai pejabat yang diserahi tugas untuk membuat akta otentik yang melayani kepentingan publik, dan kualifikasi seperti itu diberikan kepada Notaris. Aturan hukum sebagaimana tersebut di atas yang mengatur keberadaan Notaris tidak memberikan batasan atau definisi mengenai Pejabat Umum.

Setiap ada jabatan pasti terkait dengan wewenang dan setiap wewenang dari jabatan yang diembannya harus dipertanggungjawabkan. Oleh karena untuk mengetahui suatu jabatan selalu terkait

2 R Subekti dan R. Tjitrosudibio. 2004. Kitab Undang-Undang Hukum Perdata. Jakarta: Pradnya Paramita, hlm. t.h.

3 Marjanne Termoshuizen. 2002. Kamus Hukum Belanda-Indonesia. Jakarta: Djambatan, hlm. 21

4 Habib Adjie. 2008. Hukum Notaris Indonesia. Bandung: Refika Aditama, hlm. 16. 
dengan wewenang.

\section{ANALISIS DAN PEMBAHASAN}

\section{Makna Notaris Sebagai Pejabat Publik}

Dalam Wet op het Notarisambt yang mulai berlaku tanggal 3 April 1999, Pasal 1 huruf a disebutkan bahwa "Notaris: de ambtenaar", Notaris tidak lagi disebut sebagai Openbaar Ambtenaar sebagaimana tercantum dalam Pasal 1 Wet op het Notarisambt yang lama (diundangkan tanggal Juli 1842, Staatsblad 20). Tidak dirumuskan lagi Notaris sebagai Openbaar Ambtenaar, sekarang ini tidak dipersoalkan apakah Notaris sebagai Pejabat Umum atau bukan, dan perlu diperhatikan bahwa istilah Openbaar Ambtenaar dalam konteks ini tidak bermakna Umum, tetapi bermakna Publik . Ambt pada dasarnya adalah jabatan publik. Dengan demikian Jabatan Notaris adalah Jabatan Publik tanpa perlu atribut Openbaar. Penjelasan Pasal 1 huruf a tersebut di atas bahwa penggunaan istilah Notaris sebagai Openbaar Ambtenaar sebagai tautologie. ${ }^{5}$ Atau berlebihan.

Jika ketentuan dalam Wet op het Notarisambt tersebut di atas dijadikan rujukan untuk memberikan pengertian yang sama terhadap ketentuan Pasal 1 angka 1 Undang-Undang No. 30 Tahun 2004 yang menyebutkan Notaris adalah Pejabat Umum yang berwenang untuk membuat akta otentik dan kewenangan lainnya sebagaimana dimaksud dalam Pasal 15 ayat (2) dan (3) Undang-Undang No. 30 Tahun 2004. Maka Pejabat Umum yang dimaksud dalam Pasal 1 angka 1 Undang-Undang No. 30 Tahun 2004 harus dibaca sebagai Pejabat Publik atau Notaris sebagai Pejabat Publik yang berwenang untuk membuat akta otentik (Pasal 15 ayat (1) Undang-Undang No. 30 Tahun

$5 \quad$ Ibid.
2004 dan kewenangan lainnya sebagaimana dimaksud dalam Pasal 15 ayat (2) dan (3) Undang-Undang No. 30 Tahun 2004 dan untuk melayani kepentingan masyarakat. ${ }^{6}$

Notaris sebagai Pejabat Publik, dalam pengertian mempunyai wewenang dengan pengecualian. Dengan mengkategorikan Notaris sebagai Pejabat Publik. Dalam hal ini Publik yang dimaksud adalah secara yuridis masyarakat umum. Notaris sebagai Pejabat Publik tidak berarti sama dengan Pejabat Publik dalam bidang pemerintah yang dikategorikan sebagai Badan atau Pejabat Tata Usaha Negara, hal ini dapat dibedakan dari produk masing-masing Pejabat Publik tersebut. Notaris sebagai PejabatPublik produk akhirnya yaitu akta otentik, yang terikat dalam ketentuan hukum perdata terutama dalam hukum pembuktian. Akta tidak memenuhi syarat sebagai Keputusan Tata Usaha Negara yang bersifat konkret, individual dan final serta tidak menimbulkan akibat hukum perdata bagi seseorang atau badan hukum perdata, karena akta merupakan formulasi keinginan atau kehendak (wilsvorming) para pihak yang dituangkan dalam akta Notaris yang dibuat di hadapan atau oleh Notaris. Sengketa dalam bidang perdata diperiksa di pengadilan umum (negeri). Pejabat Publik dalam bidang pemerintahan produknya yaitu Surat Keputusan atau Ketetapan yang terikat dalam ketentuan Hukum Administrasi Negara yangmemenuhi syarat sebagai penetapan tertulis yang bersifat, individual dan final, yang menimbulkan akibat hukum bagi seseorang atau badan hukum perdata, dan sengketa dalam Hukum Administrasi diperiksa di Pengadilan Tata Usaha Negara. Dengan demikian dapat disimpulkan bahwa

6 Ibid. 
Notaris sebagai Pejabat Publik yang bukan Pejabat atau Badan Tata Usaha Negara. ${ }^{7}$

\section{Sejarah Perkembangan Notaris}

Jika ditelusuri sejarah Notaris dapat diketahui sejak abad ke 2-3 masehi pada masa kerajaan Romawi, di mana mereka dikenal sebagai scribae, tabellius atau notarius. Pada masa itu, mereka adalah golongan orang yang mencatat pidato. Oleh masyarakat Romawi pada waktu itu diberikan kepada mereka yang melakukan pekerjaan menulis, dimana fungsi dari Notarius sendiri pada zaman tersebut tidaklah sama dengan fungsi Notaris pada saat ini. ${ }^{8}$ Istilah Notaris diambil dari nama pengabdinya, Notarius, yang kemudian menjadi istilah/titel bagi golongan orang penulis cepat atau stenografer. Notaris adalah salah satu cabang dari profesi hukum yang tertua di dunia.

Jabatan notaris ini tidak berada di salah satu cabang kekuasaan negara, seperti di eksekutif, legislatif, ataupun yudikatif. Notaris memiliki posisi netral, sehingga apabila ditempatkan di salah satu dari ketiga badan negara tersebut maka Notaris tidak lagi dapat dianggap netral. Dengan posisi netral tersebut, Notaris diharapkan untuk memberikan penyuluhan hukum untuk dan atas tindakan hukum yang dilakukan Notaris atas permintaan kliennya. Dalan hal melakukan tindakan hukum untuk kliennya, Notaris juga tidak boleh memihak kliennya, karena tugas Notaris ialah untuk mencegah terjadinya masalah.

\section{Ibid.}

8 Abdul Ghofur Anshori. 2010. Lembaga Kenotariatan Indonesia Perspektif Hukum dan Etika. Cetakan kedua. Yogyakarta: UII Press, hlm. 8 .
Di dunia mengenai Notaris ini ada dua sistem yang berbeda, yaitu Notaris civil law yaitu lembaga notariat berasal dari italia utara dan juga dianut oleh Indonesia.Ciri-cirinya ialah: ${ }^{9}$

1. Diangkat oleh pejabat yang berwenang atau pejabat pemerintah yang berwenang;

2. Tujuan melayani kepentingan masyarakat umum;

3. Mendapatkan honorarium dari masyarakat umum.

Kemudian Notaris Common Law yaitu Notaris yang ada di negara Inggris dan Skandinavia. Ciri-cirinya ialah:

1. Akta tidak dalam bentuk tertentu;

2. Tidak diangkat oleh pejabat penguasa.

Sekitar abad ke 5, Notaris dianggap sebagai pejabat istana. Di Italia Utara sebagai daerah perdagangan utama pada abad ke 1112, dikenal Latijnse Notariat, yaitu orang yang diangkat oleh penguasa umum, dengan tujuan melayani kepentingan masyarakat umum, dan boleh mendapatkan honorarium atas jasanya oleh masyarakat umum. Latijnse Notariat ini murni berasal dari Italia Utara, bukan sebagai pengaruh hukum Romawi Kuno. Pada tahun 1888, terbitlah buku Formularium Tabellionum oleh Imerius, pendiri sekolah Bologna, dalam rangka peringatan 8 abad sekolah hukum Bologna. Berturut-turut seratus tahun kemudian ditebitkan Summa Artis Notariae oleh Rantero dari Perugia, kemudian pada abad ke 13 buku dengan judul yang sama diterbitkan oleh Rolandinus Passegeri. Ronaldinus Passegeri kemudian juga menerbitkan Flos Tamentorum. Buku-buku tersebuut menjelaskan definisi Notaris, fungsi, kewenangan dan kewajibankewajibannya.

9 Sejarah Notaris ini dikutip dari Wikipedia Bahasa Indonesia, Ensiklopedia Bebas. 
Empat istilah Notaris pada zaman Italia Utara:

1. Notarii: pejabat istana melakukan pekerjaan administratif;

2. Tabeliones: sekelompok orang yang melakukan pekerjaan tulis menulis, mereka diangkat tidak sebagai pemerintah/ kekaisaran dan diatur oleh undang-undang tersebut;

3. Tabularii: pegawai negeri, ditugaskan untuk memelihara pembukuan keuangan kota dan diberi kewenangan untuk membuat akta; Ketiganya belum membentuk sebuah bentuk akta otentik,

4. Notaris: pejabat yang membuat akta otentik.

Karel de Grote mengadakan perubahanperubahan dalam hukum peradilan Notaris, dia membagi Notaris menjadi:

1. Notarii untuk konselor raja dan kanselarij paus;

2. Tabelio dan clericus untuk gereja induk dan pejabat-pejabat agama yang kedudukannya lebih rendah dari paus.

Pada abad ke 14, profesi Notaris mengalami kemunduran dikarenakan penjualan jabatan notaris oleh penguasa demi uang di mana ketidaksiapan Notaris dadakan tersebut mengakibatkan kerugian kepada masyarakat banyak. Sementara itu, kebutuhan atas profesi Notaris telah sampai di Perancis. Pada abad ke 13, terbitlah buku Les Trois Notaires oleh Papon. Pada 6 Oktober 1791, pertama kali diundangkan undang-undang di bidang Notariat, yang hanya mengenal 1 macam Notaris. Pada tanggal 16 Maret 1803 diganti dengan Ventosewet yang memperkenalkan pelembagaan Notaris yang bertujuan memberikan jaminan yang lebih baik bagi kepentingan masyarakat umum.
Pada abad itu penjajahan pemerintah kolonial Belanda telah dimulai di Indonesia. Secara bersamaan pula, Belanda mengadaptasi Ventosewet dari Perancis dan menamainya Notariswet. Dan sesuai dengan asas konkordasi, undang-undang itu juga berlaku di Hindia Belanda/ Indonesia. Notaris pertama yang diangkat di Indonesia adalah Melchior Kelchem, sekretaris dari College van Schenpenen di Jakarta pada tanggal 27 Agustus 1620. Selanjutnya berturut turut diangkat beberapa Notaris lainnya, yang kebanyakan adalah keturunan Belanda atau timur asing lainnya.

Pada tanggal 26 Januari 1860, diterbitkannya Peraturan Notaris Reglement yang selanjutnya dikenal sebagai Peraturan Jabatan Notaris. Reglement atau ketentuan ini bisa dibilang adalah kopian dari Notariswet yang berlaku di Belanda. Peraturan jabatan Notaris terdiri dari 66 pasal. Peraturan jabatan Notaris ini masih berlaku sampai dengan diundangkannya Undang-undang No. 30 Tahun 2004 tentang Jabatan Notaris. Setelah Indonesia merdeka pada tanggal 17 Agustus 1945, terjadi kekosongan pejabat Notaris dikarenakan mereka memilih untuk pulang ke Negeri Belanda. Untuk mengisi kekosongan ini, pemerintah menyelenggarakan kursuskursus bagi warga negara Indonesia yang memiliki pengalaman di bidang hukum (biasanya wakil Notaris). Jadi, walaupun tidak berpredikat sarjana hukum saat itu, mereka mengisi kekosongan pejabat Notaris di Indonesia.

Selanjutnya pada tahun 1954, diadakan kursus-kursus independen di Universitas Indonesia. Dilanjutkan dengan kursus Notariat dengan menempel di Fakultas Hukum, sampai tahun 1970 diadakan Program Studi Spesialis 
Notariat, sebuah program yang mengajarkan keterampilan (membuat perjanjian, kontrak, dan lain-lain) yang memberikan gelar sarjana hukum (bukan CN-Candidate Notaris/Calon Notaris) pada lulusannya. Pada tahun 2000, dikeluarkan sebuah Peraturan Pemerintah No. 60 Tahun 2000 yang membolehkan penyelenggaraan Spesialis Notariat. Peraturan Pemerintah ini mengubah Program Studi Spesialis Notarist menjadi Program Magister yang bersifat keilmuan, dengan gelar akhir Magister Kenotariatan. Yang menghendaki profesi Notaris di Indonesia adalah Pasal 1868 Kitab Undang-Undang Hukum Perdata yang berbunyi: "Suatu akta otentik ialah suatu akta di dalam bentuk yang ditentukan oleh undang-undang, yang dibuat oleh atau dihadapan pegawai-pegawai umum yang berkuasa untuk itu ditempat di mana akta dibuatnya." Sebagai pelaksanaan pasal tersebut, diundangkanlah Undang-Undang No. 30 Tahun 2004 tentang Jabatan Notaris (sebagai pengganti Staatblad 1860 No. 30).

\section{Aspek-Aspek Hukum Administrasi Pada Jabatan Notaris}

HukumAdministrasi mengatur bagaimana pemerintah menjalankan wewenangnya untuk memberikan pelayanan kepada masyarakat agar masyarakat sejahtera. Subyek pemerintah memang mengalami perluasan tidak terbatas pada jabatan pemerintahan secara struktural. Pada dasarnya wewenang hukum publik dikaitkan selalu pada jabatan publik yang merupakan organ pemerintahan (bestuurs orgaan) dan menjalankan wewenangnya dalam fungsi pemerintahan, yang dalam segala tindakannya selalu dilakukannya demi kepentingan umum atau pelayanan umum (public service). Pada organ pemerintahan yang demikian, melekat pula sifatnya sebagai pejabat umum (openbaar gezag). ${ }^{10}$

Jabatan Notaris merupakan suatu lembaga yang diciptakan oleh Negara. Menempatkan Notaris sebagai jabatan merupakan suatu bidangpekerjaanatautugasyangsengajadibuat oleh aturan hukum untuk keperluan dan fungsi tertentu (kewenangan tertentu) serta bersifat berkesinambungan sebagai suatu lingkungan pekerjaan tetap. Kedudukan Notaris sebagai pejabat umum memberikan wewenang kepada Notaris untuk dapat membuat akta-akta autentik. Sebelum menjalankan jabatannya, Notaris harus disumpah terlebih dahulu. Hal ini sebagai konsekuensi bahwa dalam menjalankan jabatannya, Notaris sebagai pejabat umum harus senantiasa menghayati sumpah jabatannya yang termuat dalam Pasal 4 Undang-Undang Jabatan Notaris. Sebagaimana dikatakan oleh Liliana Tedjosaputro bahwa:

Pada asasnya jabatan Notaris ini juga seharusnya memberikan keadilan yang menuju kepada keselarasan, keserasian, keseimbangan, tidak memihak kepada para pihak dan juga bebas dari kekuasaan eksekutif. Hal ini sebenarnya menegaskan bahwa jabatan sebagai Notaris haruslah independen, dalam arti kata tidak memihak kepada pihak -pihak tertentu, sehingga notaris menjadi jabatan kepercayaan. Selain sebagai jabatan kepercayaan, Notaris juga berperan sebagai pelayan kepentingan umum serta mengatur secara tertulis 11 dan autentik hubungan-hubungan

10 M. Hadin Muhjad. TT. Komentar Terhadap Undang-undang Nomor 30 Tahun 2014 tentang Administrasi Pemerintahan. Yogyakarta: Genta Publishing, hlm. 78

11 Liliana Tedjosaputro. 2003. Etika Profesi dan Profesi Hukum. Semarang: CV. Aneka Ilmu, hlm. 
hukum antara para pihak yang secara mufakat meminta jasa Notaris, maka Notaris dituntut mempunyai pengetahuan yang luas serta tanggung jawab yang besar terhadap segala hal yang telah dilakukannya. Notaris sebagai pejabat umum menjalankan sebagian dari fungsi negara terutama dalam memberikan pelayanan kepada masyarakat umum, khususnya membuat alat bukti tertulis dan autentik dari perbuatan hukum yang dibuat atau diadakan oleh para pihak. Hal demikian menjadi keharusan oleh karena akta autentik lahir jika dibuat oleh atau dihadapan pejabat umum.

Dilihat dari pengangkatannya, disebut sebagai Pejabat Umum, karena Notaris diangkat dan diberhentikan oleh Pemerintah melalui Menteri Hukum dan HAM.Pasal 2 Undang-Undang No. 2 Tahun 2014 menentukan bahwa Notaris diangkat dan diberhentikan oleh Pemerintah, dalam hal ini Menteri yang membidangi kenotariatan (Pasal 1 ayat angka 14 Undang-Undang No. 2 Tahun 2014). Notaris meskipun secara administratif diangkat dan diberhentikan oleh pemerintah, tidak berarti Notaris menjadi subordinasi (bawahan) yang mengangkatnya yaitu Pemerintah. Dengan demikian Notaris dalam menjalankan tugas jabatannya: ${ }^{12}$

1. Bersifat mandiri (autonomous);

2. Tidak memihak siapapun (impartial);

3. Tidak tergantung kepada siapapun (independent), yang berarti dalam menjalankan tugas jabatannya tidak dapat dicampuri oleh pihak yang mengangkatnya atau oleh pihak lain.

Tidak menerima gaji atau pensiun dari yang mengangkatnya. Notaris meskipun diangkat

89

12 Habib Adjie . Loc.cit. dan diberhentikan oleh pemerintah tapi tidak menerima gaji, pensiun dari pemerintah. Notaris hanya menerima honorarium dari masyarakat yang telah dilayaninya atau dapat memberikan pelayanan cuma-cuma untuk mereka yang tidak mampu. Kehadiran Notaris untuk memenuhi kebutuhan masyarakat yang memerlukan dokumen hukum (akta) otentik dalam bidang hukum perdata, sehingga Notaris mempunyai tanggungjawab untuk melayani masyarakat menggugat secara perdata Notaris, dan menuntut biaya, ganti rugi dan bunga jika ternyata akta tersebut dapat dibuktikan dibuat tidak sesuai dengan aturan hukum yang berlaku, hal ini merupakan bentuk akuntabilitas Notaris kepada masyarakat.

Dilihatdaritugasnya, Notarismenjalankan tugas Negara, akta yang dibuatnya merupakan dokumen Negara. Jadi tugas utama atau kewenangannya Notaris yaitu membuat aktaakta otentik guna melayani (atas permintaan) masyarakat. Setiap wewenang yang diberikan kepada jabatan harus ada dasar hukumnya. sebagai landasan agar jabatan dapat berjalan dengan benar yang tidak disalah gunakan wewenangnya dan berlaku sewenang-wenang. Wewenang Notaris hanya dicantumkan dalam Pasal 15 ayat (1), (2) dan (3) UUNo. 2 Tahun 2014. Menurut Pasal 15 ayat (1) bahwa wewenang Notaris adalah membuat akta. Ada beberapa akta otentik yang merupakan wewenang Notaris dan juga menjadi wewenang pejabat atau intansi lain, yaitu:

1. Akta pengakuan anak di luar kawin (Pasal $281 \mathrm{BW}$ );

2. Akta berita acara tentang kelalaian pejabat penyimpan hipotik (Pasal $1227 \mathrm{BW}$ );

3. Akta berita acara tentang penawaran pembayaran tunai dan konsinyasi (Pasal 
1405 dan 1406 BW);

4. Akta protes wesel dan cek (Pasal 143 dan 218 WvK);

5. Surat Kuasa Membebankan Hak Tanggungan (SKMHT)-(Pasal 15 ayat (1) Undang-Undang Nomor 4 Tahun 1996).

6. Membuat akta risalah lelang .

Pasal 15 ayat (3) Undang-Undang No.2 Tahun 2014 merupakan wewenang yang akan ditentukan kemudian berdasarkan aturan hukum lain yang akan datang kemudian (ius constituendum). Berkaitan dengan wewenang tersebut, jika Notaris melakukan tindakan di luar wewenang yang telah ditentukan, maka Notaris telah melakukan tindakan di luar wewenang, maka produk atau akta Notaris tersebut tidak mengikat secara hukum atau tidak dapat dilaksanakan (nonexecutable), dan pihak atau mereka yang merasa dirugikan oleh tindakan Notaris diluar wewenang tersebut, maka Notaris dapat digugat secara perdata ke pengadilan negeri.

Kewenangan Notaris menurut Pasal 15 Undang-Undang No. 2 Tahun 2014:

1. Membuat akta otentik mengenai semua perbuatan, perjanjian, dan ketetapan yang diharuskan oleh peraturan perundangan dan/atau yag dikhendaki oleh yang berkepentingan, untuk dinyatakan dalam akta otentik, menjamin kepastian tanggal pembuatan akta, menyimpan akta, memberikan grosse, salinan dan kutipan akta, semuanya sepanjang pembuatan akta tersebut tidak ditugaskan atau dikecualikan kepada pejabat atau orang lain yang ditetapkan oleh undang-undang.

2. Mengesahkan tanda tangan dan menetapakan kepastian tanggal pembuatan surat di bawah tangan dengan mendaftar dalam buku khusus (legalisasi).

Legalisasi adalah tindakan mengesahkan tanda tangan dan menetapkan kepastian tanggal surat di bawah tangan yang dibuat sendiri oleh orang perseorangan atau oleh para pihak di atas kertas yang bermaterai cukup yang di tanda tangani di hadapan Notaris dan didaftarkan dalam buku khusus yang disediakan oleh Notaris.

1. Membukukan surat-surat di bawah tangan dengan mendaftar dalam buku khusus (waarmerking);

2. Membuat kopi dari asli surat di bawah tangan berupa salinan yang memuat uraian sebagaimana ditulis dan digambarkan dalam surat yang bersangkutan;

3. Melakukan pengesahan kecocokan fotokopi dengan surat aslinya (legalisir);

4. Memberikan penyuluhan hukum sehubungan dengan pembuatan akta;

5. Membuat akta yang berhubungan dengan pertanahan;

6. Membuat akta risalah lelang;

7. Membetulkan kesalahan tulis dan/atau kesalahan ketik yang terdapat pada minuta akta yang telah di tanda tangan, dengan membuat berita acara (BA) dan memberikan catatan tentang hal tersebut padaminuta akta asli yang menyebutkan tanggal dan nomor BA pembetulan, dan salinan tersebut dikirimkan ke para pihak (Pasal 51 Undang-Undang No. 30 Tahun 2014).

Dengan konstruksi kewenangan seperti tersebut di atas, maka ketentuan Pasal 50 Kitab Undang-undang Hukum Pidana (KUHP), dapat diterapkan kepada Notaris dalam menjalankan tugas jabatannya. Sepanjang pelaksanaan tugas jabatan tersebut sesuai dengan tata cara yang sudah ditentukan 
dalam Undang-Undang No. 2 Tahun 2014, hal ini sebagai perlindungan hukum terhadap Notaris dalam menjalankan tugas jabatannya atau merupakan suatu bentuk immunitas terhadap Notaris dalam menjalankan tugas jabatannya sesuai aturan hukum yang berlaku.

Syarat diangkat menjadi Notaris sesuai dengan Pasal 3 Undang-Undang No. 2 Tahun 2014 adalah warga negara Indonesia, karena Notaris adalah pejabat umum yang menjalankan sebagian dari fungsi publik dari negara, khususnya di bagian hukum perdata. Kewenangan ini tidak dapat diberikan kepada warga negara asing, karena menyangkut dengan menyimpan rahasia negara, Notaris harus bersumpah setia atas Negara Republik Indonesia, sesuatu yang tidak mungkin bisa ditaati sepenuhnya oleh warga negara asing. Berumur minimal 27 tahun, dianggap sudah stabil secara mental dan emosional.

Notaris hanya berkedudukan di satu tempat di kota/kabupaten, dan memiliki kewenangan wilayah jabatan seluruh wilayah provinsi dari tempat kedudukannya. Notaris hanya memiliki 1 kantor, tidak boleh membuka cabang atau perwakilan dan tidak berwenang secara teratur menjalankan jabatan dari luar tempat kedudukannya, yang artinya seluruh pembuatan akta harus sebisa mungkin dilaksanakan di kantor notaris kecuali pembuatan akta-akta tertentu. Notaris dapat membuat perserikatan perdata, dalam hal ini mendirikan kantor bersama Notaris, dengan tetap memperhatikan kemadirian dan kenetralannya dalam menjalankan jabatan Notaris.

Setiap Notaris ditempatkan di suatu daerah berdasarkan formasi Notaris. Formasi Notaris ditentukan oleh Menteri Hukum dan HAM, berdasarkan Peraturan Menteri Hukum dan HAM No. 27 Tahun 2016 tentang
Formasi Jabatan Notaris dan Penentuan Kategori Daerah dengan mempertimbangkan usul dari organisasi Notaris. Formasi Notaris ditentukan berdasarkan:

1. Kegiatan dunia usaha;

2. Jumlah penduduk;

3. Rata-rata jumlah akta yang dibuat oleh dan/atau di hadapan notaris setiap bulannya.

Sebagai pejabat umum, Notaris memiliki jam kerja yang tidak terbatas. Untuk itu Notaris memiliki hak cuti. Ketentuan mengenai cuti Notaris menurut Undang-Undang No. 2 Tahun 20014 (Pasal 25-32):

1. Hak cuti bisa diambil setelah Notaris menjalankan jabatannya secara efektif selam 2 tahun;

2. Selama cuti, Notaris harus memilih Notaris pengganti;

3. Cuti bisa diambil setiap tahun atau diambil sekaligus untuk beberapa tahun;

4. Setiap pengambilan cuti maksimal 5 tahun sudh termasuk perpanjangannya;

5. Selama masa jabatan notaris, jumlah waktu cuti paling lama ialah 12 tahun;

6. Permohonan cuti diajukan ke:

a. Majelis Pengawas Daerah, untuk cuti tidak lebih dari 6 bulan;

b. Majelis Pengawas Wilayah, untuk cuti 6 bulan sampai dengan 1 tahun;

c. Majelis Pengawas Pusat, untuk cuti lebih dari 1 tahun.

7. Selain Notaris itu sendiri, dalam keadaan terdesak, suami/istri atau keluarga sedarah dalam garis lurus dari Notaris dapat memohonkan permohonan cuti kepada majelis pengawas;

8. Apabila permohonan cuti diterima maka akan dikeluarkan sertifikat cuti yang dikeluarkan oleh pejabat yang ditunjuk;

9. Apabila permohonan cuti ditolak oleh 
pejabat yang berwenang memberikan cuti, maka penolakan itu harus disertai oleh alasan penolakan;

10. Notaris yang cuti wajib menyerahkan protokol Notaris ke Notaris pengganti.

- Apabila pada saat cuti, Notaris meninggal dunia, maka Notaris yang menggantikannya menjalankan jabatannya. Suami/istri atau keluarga sedarah dalam garis lurus dari Notaris wajib melaporkannya kepada Majelis Pengawas Daerah dalam jangka waktu 7 hari kerja sejak Notaris itu meninggal.

Pengawasan Notaris menurut UU No. 2 Tahun 2014 (Pasal 67-81) Notaris merupakan jabatan yang mandiri dan tidak memiliki atasan secara struktural, jadi Notaris bertanggung jawab langsung kepada masyarakat. Pengawas Notaris adalah Menteri Hukum dan HAM, yang dalam rangka mengawasi Notaris membentuk Majelis Pengawas berdasarkan Peraturan Menteri Hukum Dan Hak Asasi Manusia Republik Indonesia Nomor : M.02. Pr.08.10 Tahun 2004 tentang Tata Cara Pengangkatan Anggota, Pemberhentian Anggota, Susunan Organisasi, Tata Kerja,Dan Tata Cara Pemeriksaan Majelis Pengawas Notaris, dengan unsur:

1. Pemerintah; Sebagai penguasa yag mengangkat pejabat Notaris.

2. Notaris; Notaris dilibatkan karena notaris yang mengetahui seluk-beluk pekerjaan Notaris.

3. Akademisi. Kehadirannya dikaitkan dengan perkembangan ilmu hukum, karena lingkup kerja notaris bersifat dinamis dan selalu berkembang.

Yang diawasi oleh majelis pengawas:

1. Tingkah laku Notaris;

2. Pelaksanaan jabatan Notaris;

3. Pemenuhan kode etik Notaris, baik kode etik dalam organisasi Notaris ataupun yang ada dalam Undang-Undang No. 30 Tahun 2014;

Organisasi Notaris adalah wadah perkumpulan Notaris. Di Indonesia, hanya ada satu organisasi yang diakui yaitu Ikatan Notaris Indonesia (INI). INI telah ada dari awal munculnya profesi Notaris di Indonesia. Berdasarkan ketentuan Anggaran Perkumpulan Notaris yang terakhir telah disahkan oleh Menteri Kehakiman Republik Indonesia tanggal 23 Januari 1995 Nomor C2-10221.HT.01.06 Tahun 1995 dan telah diumumkan dalam Berita Negara Republik Indonesia tanggal 7 April 1995 Nomor 28 Tambahan No.1/P-1995,wadah yang diakui hanya satu karena wadah profesi ini memiliki satu kode etik. Dan juga diakui oleh Kementerian Hukum dan HAM, sesuai dengan Keputusan Menteri Hukum dan HAM No.M.01/2003 Pasal 1 butir 13.

\section{PENUTUP}

Notaris adalah sebuah jabatan yang termasuk dalam ruang lingkup Hukum Administrasi karena seorang Notaris diangkat dan diberhentikan oleh Pemerintah. Kewenangannya adalah membuat akta authentik untuk pembuktian yang merupakan rahasia negara. Dalam pekerjaannya Notaris diawasi oleh Majelis Pengawas Notaris. Sebagai pejabat publik maka Notaris tunduk pada peraturan perundang-undangan yang mengatur tentang seluruh kegiatannya selaku Notaris. Dengan kata lain pekerjaan Notaris tidak dikendalikan oleh kemauan pribadinya sendiri.

\section{BIBLIOGRAFI}

Termoshuizen, Marjanne. 2002. Kamus Hukum Belanda-Indonesia. Jakarta: Djambatan. 
Tedjosaputro, Liliana. 2003. Etika Profesi dan Profesi Hukum. Semarang: CV. Aneka Ilmu.

Subekti, R.dan R. Tjitrosudibio. 2004. Kitab Undang-Undang Hukum Perdata. Jakarta: Pradnya Paramita.

Adjie, Habib. 2008. Hukum Notaris Indonesia. Bandung: Refika Aditama.

Anshori, Abdul Ghofur. 2010. Lembaga Kenotariatan Indonesia Perspektif Hukum dan Etika. Cetakan kedua. Yogyakarta: UII Press.

Muhjad, M. Hadin. 2016. Komentar Terhadap Undang-undang Nomor 30 Tahun 2014 tentang Administrasi Pemerintahan. Yogyakarta: Genta Publishing.

Wikipedia Bahasa Indonesia. Ensiklopedia Bebas.

Peraturan perundang-undangan

Undang-Undang No. 30 Tahun 2004 tentang Jabatan Notaris

Undang-undang No. 2 Tahun 2014 tentang Perubahan Atas Undang-Undang No. 30

Tahun 2004 tentang Jabatan Notaris 